\title{
Social Impacts of the Abaca Bunchy Top Disease and Adaptive Strategies of Farm Households: A Case in Leyte, Philippines
}

\author{
Jedess Miladel C. Nuñez \\ National Abaca Research Center, Visayas State University, Visca, Baybay City, \\ Leyte 6521-A, Philippines
}

\begin{abstract}
The abaca industry is in crisis because of the bunchy-top disease which has destroyed thousands of hectares of abaca (Musa textilis Nee). While government and research efforts are focused on the eradication of the disease, this study brings attention to the changes in people's livelihoods and conditions due to the decline of their agricultural and economic productivity as well as their adaptive responses to these impacts and explanations for these. The income loss experienced by households when their crops were destroyed by the combination of the abaca bunchy top disease (ABTD) and inappropriate use of herbicides had secondary impacts to businesses in and near the village. The loss of income led to flow-on impacts on households' food security, education, health and even psychosocial well-being. However, small landowning households (less than 10ha) were more affected than those with medium-sized farms (10-30ha) in that the changes they experienced were more severe in terms of the quality and quantity of their food and budget for their children's education. Moreover, households' access to resources influenced the kind of strategies they employed, with small landowners generally engaged in wage labor, credits and loans and small enterprises to earn income. Medium landowners were generally independent of loans and one such landowner was able to engage in a profitable new enterprise (furniture-making). This case study's focus shifted from the disease to the affected population and their adaptive responses. Moreover, it looked at the affected population as a stratified society affected by and responding to a disaster differently according to their access to resources.
\end{abstract}

Keywords: crop disease, cropping pattern, enterprise

Correspondence: J.M.C. Nuñez Address: National Abaca Research Center, Visayas State University, Visca, Baybay City,Leyte6521-A, PhilippinesE-mail:jedessmilade113@yahoo.com Tel.No.:(053)335-2653

DOI: $10.32945 /$ atr3525.2013 


\section{INTRODUCTION}

Crop diseases have led to extensive damage and decline in agricultural productivity. One such crop disease is the abaca bunchy top disease (ABTD) caused by the abaca bunchy top virus (ABTV) carried by the brown aphid Pentalonia nigronervosa. Infected crops exhibit discoloration of leaves from green to orange or yellow, bunching of leaves, and stunted growth (see Plates 1a and 1b). Therefore, infected plants cannot be harvested. The spread of the disease is facilitated by the rapid reproductive rate of its vector, $P$. nigronervosa, which multiplies fast at a rate of 1-4 nymphs per aphid per day while regeneration lasts for 17 days. These vectors move from one plant to the next by crawling and flying, but the fastest methods of dispersal are human activities such as harvesting, when vectors cling to clothes and harvesting instruments, and transport of infected plant parts and planting materials from one area to another (Raymundo \& Bajet, 2000).

The high incidence of ABTD in the Philippines was primarily confined to the Bicol Region, the top producer of abaca, but it subsequently spread to other abaca-producing regions in the country (Bajet \& Magnaye, 2002). The infection reached alarming rates in Eastern Visayas, the second largest abaca-producing region, when two of its provinces (Leyte and Samar) were put in a state of calamity. The disease reportedly wiped out 16,737 ha of a total of 26,374 hectares of abaca plantations (Manila Bulletin, 2003).

Although crop diseases, such as ABTD, receive less attention than diseases affecting humans and animals (Vurro et al. 2010), they have the potential to affect farm households' agricultural production, daily subsistence and way of life as well as impact those beyond directly affected communities. However, these impacts have not been well studied (Nganje et al., 2004; Guenther et al., 2001). Moreover, while some studies (Nganje et al., 2004; Windels, 1999; McMullen et al., 1997) attempt to document flowon impacts and adaptive strategies, the majority of these focus on production losses and impacts on prices and markets. This macro-level research only gives a general idea of losses and does not detail how losses are borne differently by various social groups. It also overlooks the fact that farming households may be affected to different degrees.

Through a case study of the abaca bunchy top disease (ABTD) in an abaca-growing village in Leyte, Philippines, the impacts of a crop disease on farm households, the degree to which they are affected and how they responded to programs and policies designed to assist them were 
documented. This study also examined how this abaca-dependent group of farmers responded to changes in their livelihoods and conditions due to the declining agricultural and economic productivity and provided explanations for these adaptive strategies. Through these, the research contributes to the development of more appropriate programs and policies to address and integrate the needs of farming households.

\section{METHODOLOGY}

The study used the case study design. It was conducted in Brgy. Pinamonoan, Mahaplag, Leyte (Map 1) where most, if not all, of the residents were abaca farmers. At the time of the 2000 census, Brgy. Pinamonoan had a population of 1,101 distributed among 185 households (National Statistics Office, 2000). Before the widespread occurrence of ABTD, the majority of the residents grew abaca as their main crop. The village had a total land area of 938.12 ha, 332.6 ha of which was planted with abaca.

Information on the occurrence of ABTD, its impacts and the adaptive strategies of farm households were gathered from 20 January to 14 February 2011 through semi-structured interviews and focus group discussions (FGDs) with farmers and key informants. The purpose of the interviews was explained and the consent of the informants was obtained before interviews started. The household is the unit of analysis because it is assumed that decisions about production, investment, consumption and the mobilization of resources and assets are taken primarily at the household level (Blaikie et al., 1994; Corbett 1988). Thirty-eight household heads and members of 32 households who cultivated abaca (currently or formerly) were involved in the household interviews and were classified according to the area of land they owned: $<10$ ha (small landowner), 10-30 ha (medium landowner) (Food and Agriculture Organization 2003). The interview guide was designed to gather information on the respondents' personal details, land and assets and livelihood. It assessed their experiences with abaca farming, the occurrence of ABTD on their farms, its impacts, the adaptive strategies they employed and the assistance they received from government and nongovernment organizations.

Focus group discussions involving six male and sixteen female farmers were also conducted to confirm the information gathered in the interviews and to gather additional information. Discussions centered on 
questions similar to the ones used in household interviews.

Map 1. Map of the study site: Brgy, Pinamonaon, Mahaplag, Leyte

Source: Ecological Farm and Resource Management Institute (ECOFARMI) (2011)

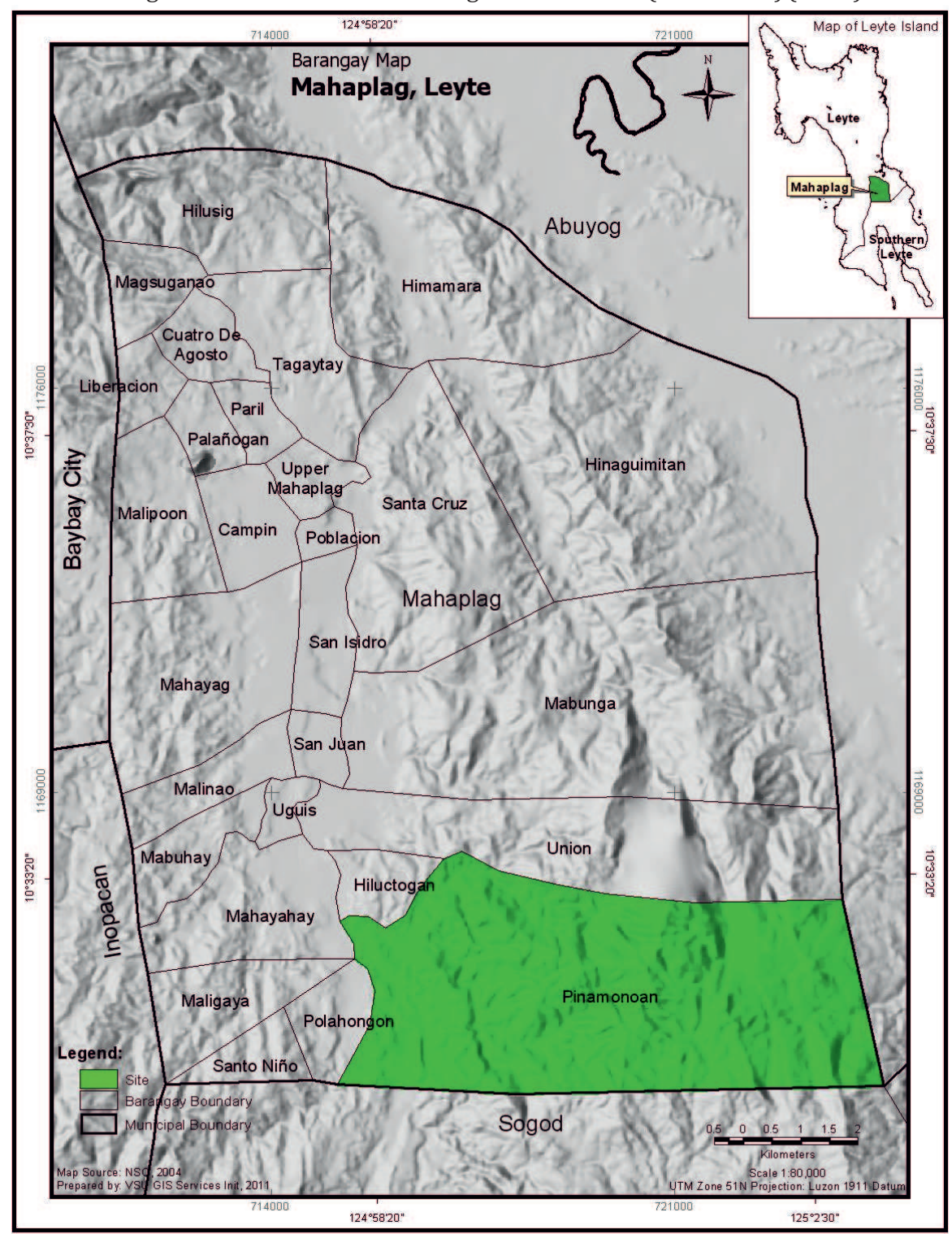


Abaca bunchy top disease and adaptive strategies

Interviews with key informants - extension workers/agricultural technicians, municipal and barangay officials - were designed to gather information on the situation of abaca production before and after ABTD, the changes they observed in the lives of the affected farmers and their households, the assistance they received, and the challenges met in conducting eradication and assistance programs in the village.

\section{RESULTS AND DISCUSSION}

\section{Abaca Bunchy Top Disease: the making of an agricultural disaster}

Brgy. Pinamonoan had productive abaca farms before the severe infection of ABTD in the late 1990s. Almost all of its residents were abaca farmers who had been growing abaca for most of their lives. For some, this is what they had always known as their parents had also grown abaca. Prior to the ABTD outbreak, abaca was their main source of income with some farmers growing secondary crops including coconut, banana, root crops and rice. It was an important part of their way of life. Couples started planting abaca when they got married to support their families. Crops could be harvested after eighteen months to two years, around the time young couples were having their first child. After initial planting, suckers continued to grow and reproduce so that a well-tended farm could produce crops that were harvestable every three to four months. In Brgy. Pinamonoan, harvesting in bulk was done two to four times a year but farmers commonly harvested weekly to cover their weekly expenses. If they needed money, they just went to their farms and harvested some abaca. Even when the price of fiber was very cheap (there was a time when JK fiber was P2/kg or 5 cents $/ \mathrm{kg}$ ) and machine-stripped fiber was $\mathrm{P} 4 / \mathrm{kg}$ or 10 cents $/ \mathrm{kg}$ ), according to informants they had an 'easy life' because their farms were very productive. The high productivity of abaca also opened opportunities for hired labor so even if some farmers did not yet have harvestable crops, they could earn an income by working on other farms.

According to a FIDA official, ABTD originated in Jagna, Sogod, Southern Leyte and spread to the next village of Polahongon and then to Pinamonaon. In 1998, the infection became severe and informants reported that their crops looked like 'indoor plants' and would not grow. They brought a sample of infected crops to the Fiber Industry Development Authority (FIDA) and the Municipal Agriculture Office (MAO) offices in the town. However, the agricultural technicians from FIDA and MAO could not 
identify it initially and referred it to researchers at the Visayas State University (VSU) who identified it as bunchy top disease. According to informants, entire farms were infected within months to a year. In 1999 and 2000 , it infected all of the farms in the village.

The gathering of the dried leafsheath or umbac, which facilitates the rapid spread of the aphid vector (Pentalonia nigronervosa), is regarded as the main cause of the rapid spread of ABTD in the village, although this has not been proven. However, people in the village had different theories and perceptions of how the disease spread on their farms. Some attributed it to the application of fertilizer (urea). Another said that she observed a helicopter drop something near her farm around the time the disease spread. She also observed an omen when the disease started. Another believed that the disease was a curse from God, a punishment for not giving the right amount of tithes and offerings. There were also conflicting statements as to where the disease started in the village. Some said farms in the mountains were infected first before the disease spread to crops near the village proper, while others said the reverse occurred.

The massive loss of crops was not caused by ABTD alone. In 2000, FIDA conducted eradication activities which involved chemical pesticides: insecticides to kill the vector and herbicides for infected crops. Informants recall that there were two herbicides used: Roundup and 2,4-D (2,4-2,4Dichlorophenoxyacetic acid). Although FIDA conducted seminars to demonstrate the use of these pesticides to farmers, it was mainly women who attended the seminars as their husbands continued to work on the family farms. A municipal councilor and chairman for agriculture claimed that the women did not correctly relay the information to their husbands, while other accounts state that the pesticides were left for distribution with some villagers without proper instructions on their use and effects. The term 'medicine' was inappropriately used by technicians to refer to the pesticides. Farmers, thinking that the chemicals were 'medicine', applied the herbicides even to healthy crops in the belief that it would prevent them from getting infected. Instead, healthy crops died along with the infected ones, leaving farmers disappointed and angry. Farmers who applied the herbicides were further infuriated when they observed that those who did not apply herbicides had unaffected areas of abaca while their crops were totally wiped out. Thus the relationship between farmers and the government became strained. Farmers then refused to follow other eradication activities by the government, contributing to the further spread of the disease. 
Abaca bunchy top disease and adaptive strategies

Impacts of ABTD on farm households

Income

The direct impact of ABTD was loss of income. Farm households may have had other crops such as coconut, banana, root crops and fruit trees, but abaca was their main source of income. Consequently, when ABTD infected their crops, their income declined and the loss of crops meant the loss of their livelihoods. Informants whose primary source of income was abaca they were either medium landowners or small landowners - experienced economic hardships.

The loss of livelihoods and decline in income also affected small businesses in and near the village. According to the fiber and copra buyers in the village, they used to fully load two trucks with abaca fiber every week. During the time of the researcher's fieldwork, they reported that it was hard to gather even $100 \mathrm{~kg}$ of fiber. According to a store owner in the village, her business was affected by the decline in income among the residents: people bought goods from her store but they found it difficult to pay. Previously, she bought goods such as rice, sugar, salt, cooking oil and soy sauce in bulk, but she stopped buying these large quantities after ATDB. Whereas ten sacks of rice were sold out before each week ended prior to ABTD, now people could only buy a few kilograms at a time.

Food

The impact of the decline in income on the quantity and quality of food differed from household to household. Four out of the six landowners with medium-sized farms indicated that they could still afford to buy rice which is the staple food in the Filipino diet. The difference was that they used to buy rice in sacks but with the decline in their income, they could only afford to buy in gantangs (4-5 lbs or $2 \mathrm{~kg}$ ). Ten out of twenty-eight landowners with small farms stated that they had to replace rice with root crops and banana because they could not afford rice anymore. They switched to root crops because these could be easily grown on their farms and did not require many inputs (fertilizers and pesticides), unlike rice.

Although root crops are promoted by the government as a good source of nutrients, they are generally regarded as a poor man's food (Balita, 2010). In Brgy. Pinamonoan, root crops were not their staple food when they could still afford rice. However, when their circumstances changed, they switched to root crops because these could be easily grown on their 
farms and did not require many inputs (fertilizers and pesticides), unlike rice. Fish and meat, which used to be part of daily meals, were now a luxury.

\section{Education}

Across the two groups of informants, there were cases of children and young people having to leave school as a result of the disease outbreak. In nine small landowning households, children had to stop schooling, especially those in universities because their parents could not pay their tuition fees and provide allowances. Those who wanted to go to college could not. This reflects the general situation in the Philippines where the poor have a high dropout rate because they cannot afford the costs of education and need to work and earn to cover daily needs. This also shows the strong link between poverty and education. The poor cannot afford a good quality education and in turn do not qualify for well-paying jobs in a labor market where knowledge and skills are essential. The poor are thus limited to low-paying occupations, further perpetuating their poverty (Collas-Monsod, 2008; Lam, 2005).

In two households who owned medium-sized farms, however, the reason for leaving school was not a result of declining income. According to the informants, their children intentionally dropped out of school for other reasons although they could still afford to support their children's studies. A small landowner's child was able to get a college degree in spite of losing his crops to ABTD. His child got through college as a working student. Thus, while it was generally true that the increased poverty wrought by the disease outbreak proved to be a hindrance to education, there were these few exceptions.

\section{Health}

In terms of health, the most affected were household members who had illnesses but could not afford to buy medicine. Since the limited income was spent primarily on food plus other living expenses such as water and electricity, there was no money left for medicine whenever a household member got sick. Consequently, people looked for less costly alternatives such as herbs. According to Foster (1994), the poor are more affected by illness. Their poor nutritional status due to the lower quantity and quality of food intake makes them more prone to infection and serious diseases. This inability to address health problems further reduces the 
Abaca bunchy top disease and adaptive strategies

productivity of household members and resource availability, thus exacerbating poverty (ibid.).

Negative psychosocial impacts

Although this was not particularly focused on in this study, interviews revealed the emotional distress of farmers and their households as a result of ABTD. The impacts of a widespread crop disease are known to create negative psychosocial impacts such as despair, panic and frustration feelings that farmers experienced during a widespread disease outbreak affecting wheat and barley in the United States during the 1990s (McMullen etal., 1997).

"When we lost our crops, I looked at my children and cried in pity because I do not want them to experience hardships. (Anita, farmer, 28 January 2011)"

"We rested for a number of years. We had low morale because our livelihood was gone. (Maximo, farmer, 20 January 2011)"

According to Myer (1989 in Edwards 1998), people experience greater stress when the disaster or event causing it lasts for a long time or when its recurrence is uncertain. Since 1998, ABTD continues to infect farms in Brgy. Pinamonaon and although healthy re-growths have been observed in some parts, it is uncertain whether they will be infected again.

\section{Coping with disaster: farm households' adaptive strategies}

Coping is the manner in which people manage their resources in times of adverse circumstances (Blaikie et al., 1994:62). Coping strategies are the short-term responses to shock while adaptive strategies are the adjustments that are integrated into everyday activities (Devereux, 2001). Most of farm household responses reflect adaptation as these involve longer term changes in their livelihoods.

Figure 1 shows the difference between the livelihood of farm households before and after the massive loss of crops through ABTD. Before the ABTD outbreak, all 32 households had abaca as their primary crop and major source of income. This decreased significantly with the ongoing incidence of ABTD, with 22 households switching to coconut and mixed cropping. 


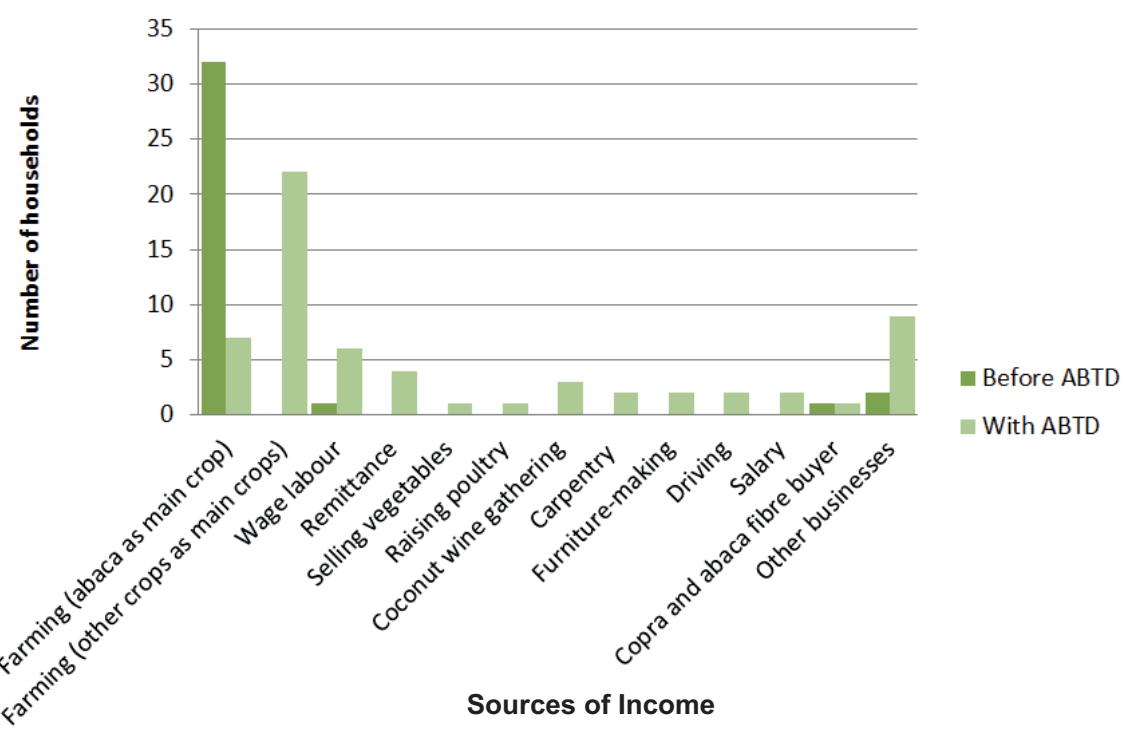

Figure 3. Farm households' income sources before ABTD and at the time of fieldwork (20 January to 14 February 2011)

\section{Change in cropping patterns}

After the occurrence of ABTD, farmers started to focus on crops that were previously less commonly cultivated. They began to plant more coconut and, in many cases, the land previously planted to abaca was converted into coconut plantations. At the time of the researcher's fieldwork, only seven out of 32 households cultivated abaca as their main crop. The rest of the informants had given up on abaca and chose coconut as the primary crop because of the high price of copra. They had also observed that coconut could not be intercropped with abaca as the roots of coconut spread under the ground, limiting the growth of abaca. Three households cultivated coconut as a monocrop while 19 employed mixed cropping.

Although informants still valued the ease, regular weekly income and high prices associated with abaca, they were aware that monocultural abaca cultivation was already. The shortage was attributed to the difficulty in re-establishing abaca farms because of the persistent disease and the scarcity of planting materials. Planting materials for abaca became scarce because of ABTD and an ordinance prohibiting the transport of abaca planting materials and other plant parts belonging to the genus Musa to 
prevent the spread of the disease.

Subsistence crops such as corn, rice, bananas, root crops and vegetables gained importance as some households found it hard to buy food. This was more common among small land owners, with 23 households cultivating said crops, although there was also a medium land owner who devoted land to these. They also sold their produce to earn money. Initial inputs for vegetable production (seeds, fertilizers and pesticides) were distributed by the Municipal Agriculture Office to assist farmers due to the loss of their crops. Unlike abaca, however, these could not be cultivated during the rainy season.

\section{Migration and remittances}

The abaca bunchy top disease was the major reason for urban migration in Brgy. Pinamonoan. According to informants, their household members began moving to Manila in 2000 when their crops were wiped out. Because life became hard for them in the village, they looked for jobs in Manila. There were cases of migration across the small and medium landowners indicating that these farm households' resources were not enough to sustain livelihoods in the deficiency of agricultural production.

Migration was an important adaptive strategy in Brgy. Pinamonoan because not only did migrants find jobs, but the benefits extended back to family members left in the village in the form of remittances. Remittances were important contributions to some of the informants' household income.

Migration usually followed the cessation of schooling as a result of crop and income loss. The usual pattern in a household was that older children moved first and settled into work before younger siblings followed. This shows the important role of familial networks in helping new migrants find a job and a place to live in (Quisumbing \& McNiven, 2005).

The situation in Brgy. Pinamonoan reflects what is happening more widely in the Philippines. Migration from rural to urban areas is mainly driven by a desire to gain better access to public services, and more importantly, to job opportunities (Quisumbing \& McNiven, 2005). In 2000, 48 per cent of the country's population resided in urban areas, mostly in the National Capital Region (NCR) (NSO, 2003), and this trend is increasing. 


\section{Wage labor}

Wage laboring on other farms was an important response used particularly by small land owners with six households engaged in labor after the occurrence of ABTD compared to only one before. Such labor included clearing, planting and harvesting coconut for copra. It was common for women to help their husbands in farm work, even during the time when they still had their abaca. However, some informants' wives who did not previously work much on the farm had to devote more of their labor to farming because of the additional labor requirements after abaca was wiped out. There was one informant whose labor needs were so great that the children were made to help in farm work and balance this with their studies. In addition to their own farm work, two male informants were engaged in carpentry jobs, while three females were engaged in domestic work as laundry women and household help within the village. Laboring alone was not sufficient as a livelihood option because the wage falls short of the minimum wage in order to be classified as non-poor.

According to Moser (1996), labor is the greatest asset of the poor and is their most frequent response to declining income. Both men and women have been mobilized to increase household income, but in very poor households, even the children are compelled to work. These children are among the most disadvantaged and more prone to risk their education (International Labour Organization, 2008).

\section{Credit and loans}

Households seek credit when they lack alternative income sources for necessities (Pryer, 2003). However, the poor are not usually considered creditworthy (Blaikie et al., 1994). This is the reason why people in the village either took loans from microcredit institutions or some became victims of loan sharks (interview with FIDA official, 26 January 2011).

The small land owners were more likely to need loans to meet even daily expenses. Medium land owners, on the other hand, declared that they depended on themselves and their own household members for financial support.

Although the loans are intended as capital to jumpstart microenterprises, these often end up being used for everyday basic expenses such as food. Informants explained they did this because they could not meet their daily expenses which took priority over new enterprises. 


\section{Mortgaging of assets}

Assets that are essential in production and income generation, such as land, are more costly to lose than those that are not (Corbett, 1988). Not only are farmers losing things they have invested in, they are also further diminishing their livelihood security in giving up their land.

Three informants had to mortgage their farms. One did this to pay for medical bills, another for her daughter's wedding and the third to cover their fare to Manila. Two of them were small landowners and one was a medium landowner.

\section{New enterprises}

Nine households undertook new enterprises other than farming. The kind and scale of business that they engaged in were influenced by the assets they had. A medium landowner had a furniture shop in the village. She employed furniture-makers and the business was doing well at the time of the researcher's field work. It became her household's main source of income. In addition, she owned small-scale businesses which involved computer gaming, videoke, and billiards.

Small landowners commonly ventured into livelihood activities that did not require much capital. These enterprises were intended to supplement their farm income which was not enough to meet their daily needs. Some sold vegetables, cooked and sold food, and drove motorcycles for a living. Motorcycles are the main mode of public transport in Mahaplag. It is the easiest way to travel particularly on backroads to villages such as Pinamonoan. Also, it is common to acquire a motorcycle through credit with monthly installments (or hulugan) which makes it possible for those with less income to purchase one.

For some, new enterprises were not always lucrative. An example of this is weaving sinamay and gathering coconut wine. According to the only sinamay weaver left in the village, there was a businessman who initiated weaving involving the women in the village. They got the fiber from him and wove the sinamay and sold it back to him. However, the price of abaca fiber increased while the price of finished product did not so most of the women stopped weaving. The price of fiber is P400/kg (USD 9) while the finished product is $\mathrm{P} 44 /$ meter (USD 1). She continues with the venture even though she does not earn much. She finishes about 30 meters in a month from $2.5 \mathrm{~kg}$ of fiber which makes her only about P320 (USD 7.40) 
profit. Another example is the coconut wine (or tuba) gatherers (or manananggot) who earn P50 (USD 1.15) per gallon of coconut wine. A 68year old farmer had to mortgage his land to pay for his wife's medical bills when she suffered from a stroke. He now works as a coconut wine gatherer for another's farm and earns about P100 (USD 2.30) from two gallons of coconut wine per day.

\section{Illegal activities}

There were incidents of thefts on farms. According to the barangay captain, some people stole bananas for food while some others stole crops in order to sell them because earnings from coconut did not always last until the next harvest time (three months). Abaca suckers were also stolen because as the disease still persisted, planting materials were scarce and inadequate for the re-establishment of farms. Moreover, farmers could not acquire planting materials from other areas because of the ordinance prohibiting this. A new ordinance prohibited the gathering of umbac or the dried leaf sheath, but this did not stop some people in the village. The barangay captain also revealed that some people in the village had become involved in illegal logging. This illustrates the extent to which people were prepared to go, including illegal activities, in order to cope with adverse livelihood circumstances.

\section{Governmentassistance}

Generally, informants did not receive assistance before the widespread occurrence of ABTD. In most cases, they did not need assistance because there were sufficient planting materials from their own farms for replanting and expansion. With the occurrence of ABTD, government assistance increased in the village, with varying results.

Farmers became wary of government programs because of the herbicide disaster. Moreover, informants found that the free suckers they received got infected. One informant who was able to grow these suckers and harvest them found that the fiber was of poor quality. The Fiber Industry Development Authority's program of disease eradication is still in progress. On December 2010, they went to some farms and sprayed existing abaca crops with insecticides and fertilizer. Some farmers did not want to take part but there were others who did and the feedback was generally positive. They observed that their crops looked healthier and 
greener. The method of herbicide application was also modified. Instead of spraying the herbicide, these farmers inserted bamboo sticks soaked in herbicide into infected plants. This way, only the infected plants were killed. To further encourage farmers to take part in eradication activities, FIDA paid P1,500 (USD 34.88) per hectare to those who participated in the program. Some farmers earned up to P15,000 (USD 348.84) from participating in these activities (interview with former barangay captain, 28 January 2011). However, those with smaller farms received a correspondingly small sum of money.

The vegetable program of DA is ongoing. DA technicians distributed free seeds of beans, okra, pepper, and onion every year. Those who received the seeds found these beneficial as the produce was both consumed by their households and at the same time contributed to their income. However, vegetables can only be cultivated during summer as they rot during the rainy season.

Government assistance does not always address farm households' needs and capabilities. This is illustrated by the discontinuation of the swine dispersal program which did not take into account the costs of swine-rearing. An informant said that she was not interested in raising swine as they consumed a lot of feed. The tilapia fingerlings were also unpopular as most farm households do not have areas in which to breed them. Similar to the loans from financial institutions, the financial support given by the Department of Social Welfare and Development (DSWD) for capital to jumpstart micro-enterprises did not achieve its purpose as farm households commonly used the loans for immediate needs and there was no return for the investment (interview with FIDA official, 26 January 2011).

Although informants knew of these programs, they were not always able to get involved because they were away working on their farms in the mountains, far from the village, and they usually spent many days at a time on these farms. One informant said she did not avail herself of the free vegetable seeds because her farm was far away and she did not have any plots near the village. This further illustrates the lack of government understanding of local situations.

There has been some success with the recent spraying of chemical insecticides and fertilizers. Informants reported good results so many others expressed interest in becoming involved. Some even expressed disappointment and anger because their farms were not included in the spraying. 
Access to government support was influenced by connections and by relationships that some villagers had with those in the various government agencies. The inequality in the distribution of aid caused tension between some of the farmers. According to one informant, some of his neighbors were angry because he got more chemical pesticides than what they received from the government. He admitted that he had many friends in the DA and that this was the reason he got the pesticides. In addition, one informant said that the village officials are usually the ones who get the benefits from the government's programs.

\section{CONCLUSION}

Framing major crop diseases as disasters opens up new areas of analyzing their impacts. It allows the shift of focus from the disease and its effects on crops to the affected population - how they are affected by and cope with a disaster. Their ability to absorb and recover from shocks was largely determined by their access to resources. Although all of the farms were infected with ABTD, the degree of impacts and responses of households differed. Households with medium-sized farms and more social networks - that is, more assets - were less affected by the loss of crops and were more likely to engage in other profitable enterprises than those with small farms. An important implication is that rural communities responding to a disaster should be viewed not as a whole, uniform entity, but as stratified societies with households that have differing capacities to absorb and recover from shocks, according to their assets. Therefore, government assistance should aim to develop livelihood strategies that are sensitive to local settings and needs, instead of merely providing production inputs. To achieve this, the participation of farm households, especially the marginalised ones, should be elicited in the development of livelihood programs.

\section{REFERENCES}

BLAIKIE P., T. CANNON, I. DAVIS and B. WISNER. 1994. At risk natural hazards, people's vulnerability, and disasters. Routledge, London.

BAJET NB and L.V. MAGNAYE. 2002. Virus diseases of banana and abaca in the Philippines. Philippine Agriculture and Resources Research Foundation, Inc. (PARRFI), Los Baños. 
Abaca bunchy top disease and adaptive strategies

COLLAS-MONSOD, S. 2008. Education and poverty reduction. Philippine Daily Inquirer.

CORBETT, J. 1988. Famine and household coping strategies. World Development 16(9):1099-1112.

DEVEREUX, S. 2001. Livelihood insecurity and social protection: a reemerging issue in social development. Development Policy Review, 19(4): 507-519.

EDWARDS, M.L.K. 1998. An interdisciplinary perspective on disasters and stress: the promise of an ecological framework. Sociological Forum, 13(1):115-132.

(FAO) 2003. Food and Agriculture Organization of the United Nations. Southland: a case study-based training exercise in policy analysis for the agricultural and rural sector. Viewed 10 June 2011, http://www.fao.org/DOCREP/006/Y5137E/y5137e07.htm.

FOSTER, A.D. 1994. Poverty and illness in low-income rural areas. The American Economic Review, 84(2):216-220.

GUENTHER, J.K., K.C. MICHAEL and P. NOLTE. 2001. The economic impact of potato late blight on US growers. Potato Research, 44(2):121-125.

INTERNATIONAL LABOUR ORGANIZATION (ILO). 2008. World Day Against Child Labour 2008 - ILO says education is the "right response" to child labour. Viewed 20 October 2010, http://www.ilo.org/global/About_the ILO/Media_and_public_information/Press_releases/lang-en/WCMS_094126/index.htm.

LAM, L.T.A. 2005. Human resource development and poverty in the Philippines. PIDS Discussion Paper Series no. 2005-17. Viewed 11 May 2011, http://dirp4.pids.gov.ph/ris/dps/pidsdps0517.pdf. 
MANILA BULLETIN. 2003. Bunchy top disease wreaks havoc on abaca and banana, 13 June. Viewed 9 October 2010,http://findarticles.com/p/newsarticles/manila-bulletin/mi_7968/is_2003_June_13/bunchy-diseasewreaks-havoc-abaca/ai_n33494385/.

MCMULLEN, M., R. JONES and D. GALLENBERG. 1997. Scab of wheat and barley: a re-emerging disease with devastating impact. Plant Disease, 81(12):1340-1348.

MOSER, C.O.N. 1996. Confronting crisis: a comparative study of household responses to poverty and vulnerability in four urban communities. The World Bank, Washington, D.C.

NATIONAL STATISTICS OFFICE (NSO) 2003, Philippines: urban population was registered at 48.0 percent. Viewed 2 November 2010, http://www.census.gov.ph/data/pressrelease/2003/pr0382tx.html.

NGANJE, W.E., D.A. BANGSUND, F.L. LEISTRITZ, W.W. WISLON and N.M. TIAPO. 2004. Regional economic impacts of fusarium head blight on wheat and barley. Review of Agricultural Economics, 26(3):332-347.

PRYER, J.A. 2003. Poverty and vulnerability in Dhaka slums: the urban livelihoods study, Ashgate Publishing Limited, England.

QUISUMBING, A.R. and S. MCNIVEN. 2005. Migration and the Rural-Urban Continuum: Evidence from the Rural Philippine. International Food Policy Research Institute, Washington DC. Viewed 20 October 2010, http://www.ifpri.org/sites/default/files/publications/fcndp197.pdf.

RAYMUNDO, A.V. and N.B. BAJET. 2000. Epidemiology and integrated management of abaca bunchy top in the Philippines. University of the Philippines. Viewed 2 November 2010, http://musalit.inibap.org/pdf/ IN010008_en.pdf.

VURRO, M., B. BONCIANI and G. VANNACCI. 2010. Emerging infectious diseases of crop plants in developing countries: impact on agriculture and socio-economic consequences. Food Security 2:113-132. 
Abaca bunchy top disease and adaptive strategies

WINDELS, C.E. 1999. Economic and social impacts of fusarium head blight: changing farms and rural communities in the Northern Great Plains. Paper presented at the $91^{\text {st }}$ Annual Meeting of The American Phytopathological Society, 8 August 1999. Viewed 2 March 2011, http://apsjournals.apsnet.org/doi/pdf/10.1094/PHYT0.2000. 90.1.17. 